\title{
THREE THESES ON THE PEDAGOGICAL RELEVANCE OF SECOND LANGUAGE ACQUISITION RESEARCH
}

\author{
Johannes Eckerth
}

\begin{abstract}
The paper investigates the relevance of second language acquisition research inside language teaching. As a point of departure, three theses are proposed, each of which suggests a relevance criterion regarding second language acquisition research. These three theses are then exemplified by reference to three empirical studies in classroom-based L2 research. In conclusion, it is suggested that the field of task-based research is one in which $L 2$ teaching and $L 2$ research can benefit from each other. It is further proposed how this might be done, such that a cooperative and constructive dialogue between teachers and researchers develops.

Keywords: Second language acquisition, pedagogical relevance of SLA research, foreign language pedagogy, classroom-based research, task-based language learning and teaching.
\end{abstract}

\section{İKINCI DIL EDINIM ARAŞTIRMASININ PEDAGOJIK İLIŞKISII ÜZERINE ÜÇ TEZ}

\section{$\ddot{O}_{\text {zet }}$}

Bu yazıda ikinci dil edinim araştırmalarının dil öğretimindeki yeri incelenmektedir. Çıkış noktası olarak, her biri ikinci dil edinim araştırmalarlyla bağlantıll bir uygunluk ölçütü getiren üç tez ileri sürülmektedir. Ardından bu üç tez sinıf ortamında ikinci dil araştırmasını temel alan üç adet ampirik çalı̧̧maya dayanılarak örneklenmektedir. Sonuç olarak, görev tabanlı araştırma alanının ikinci dil öğretimi ve ikinci dil araştırmasının birbirlerinden yararlanabilecekleri bir alan olduğu ileri sürülmektedir. Ayrıca, öğretmenlerle araştırmacılar arasında işbirliğine dayanan ve yapıcı bir diyalogun geliş̧tirilmesi için bunun nasıl sağlanabileceği önerilmektedir.

Anahtar sözcükler: İkinci dil edinimi, ikinci dil edinimi araştırmasının pedagojik uygunluğu, yabancı dil pedagojisi, sinıf tabanlı araştırma, görev tabanlı dil öğrenimi ve öğretimi. 


\section{Introduction}

The notion of 'pedagogical relevance' regarding second language acquisition research ${ }^{1}$ is unclear, as its definition depends on the perspective adopted. Let us accept that communication between 'pedagogy' and 'research' is not going to be easy, and that this difficulty is compounded by institutional factors, possibly more so than by individual factors.

In other words, second language acquisition research is institutionalised at universities and research centres, while foreign language teaching takes place in state and private schools, colleges and institutions of higher education. All too often, then, these domains constitute separate spheres of reality, which can be characterised in terms of different beliefs and convictions, types of knowledge, value systems, action patterns, linguistic conventions and discourse practices. Discourse practices are to be understood here as stemming from a "socially accepted association among ways of using language, other symbolic expressions, and 'artifacts', of thinking, feeling, believing, valuing, and acting that can be used to identify oneself as a member of a socially meaningful group or 'social network', or to signal (that one is playing) a socially meaningful "role" (Gee, 1996: 131). Discourse practices reflect then social structures, and may well differ in different professional domains. While all the factors listed by Gee are potentially disruptive for a constructive dialogue between different professional communities, I suggest that what Gee calls "a socially accepted association among ways of thinking", is particularly relevant to the issue of the pedagogical relevance of second language acquisition research.

Both L2 research and L2 teaching are grounded in continuously developing knowledge bases, but they refer to different types of knowledge, which may be labelled 'technical' as opposed to 'practical' knowledge, to use Ellis's (1997) terms. Technical knowledge is explicit in nature, it exists in a declarative and codified form. It is acquired by reflection and empirical investigation, and the latter involves well-defined procedures to ensure the validity and reliability of the knowledge thereby obtained. Finally, technical knowledge is generalised in the form of statements which cover a variety of cases, such that it is not easy to apply it in a straightforward manner in a particular circumstance, or to use it in rapid decision-making in everyday life. Practical knowledge, however, is implicit and intuitive. It is acquired through actual experience while carrying out actions by

1 In this paper, I will use the term 'second language acquisition research' (or occasionally 'L2 research') for the entire academic field concerned with the study of L2 acquisition. Likewise, I employ the term 'foreign language teaching' (or 'L2 teaching') to refer to all activities situated within L2 pedagogy. 
means of procedures that are only partly and sporadically reflected upon. As it is proceduralised, practical knowledge can be accessed quickly and efficiently, thus enabling an actant to apply it in particular cases, and in situations that call for online decision-making.

It seems nonetheless plausible to assume that at least some areas of L2 research are relevant for language teachers, e.g. classroom-based studies investigating different patterns of interaction and participation, error correction, the development and evaluation of language learning tasks, or whether and in what way grammar instruction fosters L2 acquisition. Other subfields of research, such as studies based on a theory of universal grammar, are more remote from the concerns of language practitioners. But even in areas where a content relevance might be assumed, it frequently occurs at professional conferences which bring together L2 teachers and researchers that the discussion following a presentation from the perspective of second language acquisition research demonstrates that teachers and researchers are at cross-purposes. Such discord, I would argue, is above all due to the difference between the types of knowledge mentioned (cf. e.g. Kramsch 1995, Pica 1997).

The distinction between technical and practical knowledge, if valid, suggests that we ignore traditionally and institutionally established delimitations between fields of activity at our peril. It means furthermore that a reductionist view of the notion of relevance is suspect, as the expectation that findings and implications stemming from one field can be directly taken over and 'applied' to another is not warranted. Abandoning, therefore, such a reductionist pose, I shall propose three theses concerning the pedagogical relevance of second language acquisition research. By exemplifying each of these theses with data stemming from my own research, I will attempt to shed light on different aspects of the notion of relevance.

Thesis 1:In judging the pedagogical relevance of empirical research, one must distinguish between the research process and the research product.

\section{Thesis 2:}

The immediate applicability of research results is one possible relevance criterion, but not the only one.

Thesis 3:The degree to which pedagogical relevance obtains matches the degree to which empirical research takes into consideration the inherent conditions and characteristics of the foreign language classroom.

These three proposals will be exemplified and substantiated by reference to three empirical studies carried out in different German-as-a-foreign/second- 
language classrooms in the Netherlands and in Germany. In particularly, the research reported below focuses on

(i) uptake-recall charts,

(ii) language-related learner questions, and

(iii) text reconstruction tasks.

All are concerned with the investigation of learning processes and the assessment of learning outcomes resulting from different types of classroom interaction.

\section{Test cases: Three empirical research projects}

\subsection{Uptake-recall charts}

Thesis 1 states that when talking about the relevance of second language acquisition research for foreign language teaching, one has to distinguish between the research process and the research product. I will illustrate and support this basic claim by outlining an investigation into 'uptake-recall charts'. Uptake-recall charts are retrospective notes of language learners, in which they report on what they have learned in terms of words, structures, phrases, expressions etc. in the previous lesson. The central research goal guiding the investigation reported on here was to develop a test instrument able to assess learning gains resulting from classroom interaction, and to evaluate the instrument's validity and reliability.

The psychometric assessment of learning outcomes based on classroom interaction is complicated by several factors. First of all, it cannot simply be assumed that the effect of interaction and negotiation on acquisition is immediately visible. On the other hand, however, it is not clear how acquisition based on specific types of classroom interaction can be proved by means of long-term studies, as there are numerous variables intervening in the research design, for example learning opportunities outside the classroom, or the multitude and variety of interactional events and patterns occurring in the classroom since the original behaviours whose long-term effects are supposed to be measured. A further difficulty is test construction, as there is an inherent principle of unpredictability regarding the learning opportunities arising from classroom interaction. This has been shown in empirical research on teacher-learner interaction (Slimani 1989, 1992) as well as on learners' collaborative dialogues while working on a task (Coughlan \& Duff 1994): the linguistic and cognitive activities brought about by these interactional patterns can lead to a multitude of learning opportunities which transcend the pedagogic scope of the lesson or the task. Such learning opportunities will be based on the learning problems and learning interests of individual students, leading them to a personal interpretation of the task, and thus redefining the 
activities involved in task completion. However, tests that attempt to assess the learning outcome of a lesson or a task are usually restricted to examining L2knowledge and language skills which have been formulated beforehand as the defined learning goal of the lesson or task. This represents a serious shortcoming, reducing the broad range of potential learning opportunities available in the rich variety of classroom interaction.

At the moment, there are two possible answers to this problem, the one more research-based, the other more teaching-orientated. As has been shown in research on task-based learner-learner interaction (Eckerth 2003a, under review), it is possible to reconstruct learning opportunities and to assess learning outcomes emerging from collaborative learner dialogues. Learning opportunities were defined in this research as instances in which two learners working together on an L2 task put forward conflicting assumptions regarding the form, structure, meaning or use of any aspect of the target language. Such 'Individual Learner Hypotheses' regarding aspects of the target language were first identified by a close analysis of the task-based interactions, and were then investigated by means of a dyad-specific follow-up test. In other words, test items were individualised and 'tailor-made' for each pair of students, on the basis of what they had discussed when working together on the task. (Eckerth, in prep. $)^{2}$.

Whereas such a research approach may contribute to our understanding of L2 learning based on interaction, it is clearly of limited immediate practical value, given the enormous investment of time and resources necessary, in order to identify and reconstruct learning opportunities, and then assess learning gains. In order to appraise the learning outcomes of a previous lesson, the foreign language teacher needs rather a readily available and easy-to-handle instument able to cover not just those aspects of the L2 that have been taught, but also those L2 aspects that have actually been learned.

\footnotetext{
2 The results of this research show that the tasks used contributed to the articulation, reasoning and negotiation of L2 hypotheses that lay outside the actual structural focus of the task to a considerable degree. Moreover, in more than one third of these negotiations, L2 knowledge representations not conforming with L2 norms were replaced by L2-conform representations, and integrated into learners' interlanguage in the medium term. In other words, nonconforming hypotheses voiced during task-work were replaced by answers conforming with target language norms in the tailor-made tests. In view of these learning gains, it seems clear that reflecting upon and actively hypothesising about non-target features of L2 is not to be seen as an irrelevance in terms of task completion, but rather as the learner's active contribution to task completion, based on individual learning concerns. Such activity, it is suggetsed, is rich in acquisitional potential. Furthermore, cases arise in which both learners lacked relevant L2 knowledge during the task, but the collaborative dialogue apparently promoted learning activities going beyond task completion, as they produced normative test responses. This effect has not been previously topicalised in taskbased research.
} 
It is precisely here that research into uptake-recall charts becomes relevant. Whether they constitute a suitable and at the same time a reliable way of assessing learning gains was the basic research question. As was outlined above, uptakerecall charts are retrospective notes by means of which language learners report on their subjective perception of which aspects of the target language have been learned in the previous lesson. Such reports were first used by Slimani (1989, 1992), on the basis of Allwright's concept of learner uptake (Allwright 1984), but the question of reliability was not addressed. Clearly, however, if uptake-recall charts have any role to play in language teaching, the subjectivity of the learners' accounts has to be examined more closely. To this end, an experimental research design including some statistical procedures was developed (Eckerth 1999a), investigating the reliability of learner data from uptake-recall charts by means of a translation test. The research design was as follows:

1. In three parallel German language classes in a Dutch college an L2 to L1 translation test was administered. The test encompassed 60 words (all of them job titles). Nineteen of these items were selected for didactic treatment, as the test established that at least $95 \%$ of the learners did not know them. This procedure acted as a pre-test.

2. Four weeks later, these 19 test items were taught in all three classes by their regular German teachers.

3. Immediately after the lesson the learners were asked to fill out an uptakerecall chart.("Please report all items you have learned in today's lesson. These items may encompass words and expressions, grammar, aspects of pronunciation, or how to use the language, and other aspects of German")

4. A post-test consisting of an L2 to L1 translation task of the 19 test items was given two days later for two classes, and seven days afterwards for a third.

By means of this research design it was in theory possible to assess whether and to what degree uptake-recall charts produced reliable data. Reliable data in this case was conceived as actually perceived and possibly learned words and word meanings, excluding words that were not part of the input, as well as mere word associations that were triggered by the input. The research design also addressed the effect of the time gap between uptake-recall chart and post-test (two days in classes A and B, 7 days in class C). A further point of considerable interest was whether the L1 meanings of the reported items were actually known to the students. A translation test was chosen on grounds of the heavily contrastiveoriented instruction in all three classes: however, we also recognised that knowledge of an L1 equivalent is only one part of lexical acquisition. Table 1 gives an overview of the results: 
Table 1: Variation between students and classes

\begin{tabular}{|l|l|ccccc|ccccc|}
\hline Class & Students & \multicolumn{5}{|c|}{ Uptake-recall Chart } & \multicolumn{5}{c|}{ Post-test } \\
& \multicolumn{1}{|c|}{$\mathrm{n}$} & $\mathrm{n} 1$ & $\min$ & $\max$ & $\mathrm{am}^{2}$ & $\mathrm{sd}^{3}$ & $\mathrm{n}$ & $\min$ & $\max$ & $\mathrm{am}$ & $\mathrm{sd}$ \\
\hline $\mathrm{A}$ & 16 & 135 & 4 & 16 & 8,4 & 3,3 & 245 & 6 & 19 & 15,3 & 3,8 \\
$\mathrm{~B}$ & 17 & 158 & 4 & 16 & 9,3 & 3,1 & 241 & 7 & 19 & 14,2 & 3,4 \\
$\mathrm{C}$ & 17 & 137 & 2 & 15 & 8,1 & 4,3 & 125 & 1 & 17 & 7,4 & 4,2 \\
& & & & & & & & & & & \\
$\Sigma$ & 50 & 430 & 2 & 16 & 8,6 & 3,6 & 611 & 1 & 19 & 12,2 & 5,1 \\
\hline
\end{tabular}

First of all, the table shows that every student noted at least some items (Uptake-recall Charts $\min =2$ ), no learners were unable to manage the sort of retrospective report they were asked to provide. Additionally, the qualitative analysis shows that only items that were actually part of the input were reported. Furthermore, the effect of the alternation of the time gap between recall chart and post-test is clear. Whereas the post-test data for classes A and B (2-day time gap) are analogous, the data for class $\mathrm{C}$ ( 7 days between chart and post-test) is not. This applies not only to the average number of items translated in the post-test, but also to the numeric relation between recall chart and post-test. In class A and B fewer items are reported than are translated (55\% and $65 \%$ respectively). This result can be attributed to the fact that the L2-stimuli in the post-test activated the learners' memories. In class $\mathrm{C}$, the numeric relation between charts and post-test is reversed: the number of items reported exceeds the number of items translated (110\%). A closer look at the the ratio of reported and translated items per individual learner is helpful in explaining this result. In contrast to the first ratio which is similar in all three classes (reported items per learner in class A: 8,4; B: 9,3; C: 8,1), the ratio of translated items per learner is not (A: 15,3; B: 14, 2; C: 7,4). Whereas the first characteristic can be read as supporting the robustness of uptake-recall charts, the second draws a rather disappointing picture of lexical learning gains in the medium-term as opposed to short-term memorisation. That is to say, while the students report similar numbers of words in the recall charts, their ability to recall their meaning in L1 declines rapidly within one week. Such an interpretation is further supported by the data in table 2, which shows the relationship between reported and correctly translated items: 
Table 2: Number of reported and later correctly translated items

\begin{tabular}{|l|l|l|l|}
\hline Class & reported & \multicolumn{2}{|c|}{ correctly translated } \\
\hline & $(\mathrm{n})$ & $(\mathrm{n})$ & $(\%)$ \\
\hline $\mathrm{A}$ & 135 & 128 & 95 \\
\hline $\mathrm{B}$ & 158 & 151 & 96 \\
\hline $\mathrm{C}$ & 137 & 96 & 71 \\
\hline$\sum / \Delta$ & $\hat{\mathrm{A}} 430$ & $\hat{\mathrm{A}} 375$ & $\Delta 87$ \\
\hline
\end{tabular}

Again, the results are similar in classes $\mathrm{A}$ and $\mathrm{B}$, with class $\mathrm{C}$ producing rather deviant figures. Two days after the recall charts (classes A and B) the meaning of the vast majority of the reported items (operationalised in terms of correct L2 to L1 translations) is known by the students ( 95 and $96 \%$ ), this number decreasing to $71 \%$ within one week (class C).

We may say therefore that the data analysed so far lends some support to the conclusion that the items at the time they were reported in the uptake-recall charts were not only remembered as L2 linguistic forms, but also known with respect to their L1 meaning. Not surprisingly, this learning gain decreases over time.

Finally, the overall correlation between the uptake-recall chart and the post-test should be assessed. Table 3 shows the correlation between the two sets of data for each class:

Table 3:

Correlation (Pearson Product Moment) between uptake-recall chart and posttest

\begin{tabular}{|l|l|l|l|}
\hline Class A & Class B & Class C & Total \\
\hline $.613^{* *}$ & $.839^{* *}$ & $.857^{* *}$ & $.848^{* *}$ \\
\hline
\end{tabular}

$* *=$ corr. significant at $\mathrm{p}<0.01$

Correlations between the recall chart and the post-test are statistically significant for all three classes. This can be considered as further evidence for the correspondence between the two test instruments, substantiating the concurrent validity of uptake-recall charts. To summarize: uptake-recall charts appear to elicit subjective data on what has been learned that is

(i) sincere (no items reported that were not in the input),

(ii) robust and reliable (similar data patterns across three different classes), and

(iii) valid (consistency of data from recall charts and translation tests). 
Further research and replication studies, systematically varying the relevant variables, is needed to test whether the assumption that uptake-recall charts are valid and reliable evaluation and assessment tools, suitable to be readily employed in foreign language teaching, receives further support ${ }^{3}$.

Although this research work was carried out inside an existing curriculum with regular language classes, rather than being conducted as a laboratory experiment, the design and realisation of the study was highly controlled, and the statistical analysis used was quite technical in nature. Thus, with respect to thesis 1 above, I conclude that whereas the research process was quite remote from the everyday business of foreign language teaching, the research result is of immediate potential benefit for language pedagogy. Such a division - a rather 'technical' process of evaluation, as opposed to a quite 'practical' and readily applicable product matches the two types of knowledge mentioned above, and can be seen as characteristic of L2 research and L2 teaching communities respectively.

\subsection{Language-related learner questions}

Thesis 2 claims that the immediate applicability of research results in foreign language teaching is a possible condition for pedagogical relevance, but not a necessary one. The investigation of so called language-related learner questions, i.e., questions asked by learners concerning the structure, function or use of the foreign language is, I now wish to suggest, one example of research which is relevant for foreign language pedagogy, but not immediately applicable in terms of didactic techniques or teaching procedures. The investigation I shall refer to is reported on in Eckerth (1998).

The methodological goal of the investigation was to develop a research design that could be implemented in the regular L2 classroom, without interfering with classroom interaction patterns. The main objective of the study of language-related learner questions was to analyse learners' mental construction of L2-hypotheses as a reaction to the perceived input. The primary data consisted of 26 hours of videotaped instruction in two university German-as-a-Second-Language classrooms intensive courses for lower and upper intermediate learners. Additionally, retrospective interviews were held with those learners who had been observed to initiate language-related questions. The third data set is formed by a questionnaire (see Eckerth, 1998 for interview and survey data analysis).

Transcript 1 shows how learner-initiated reflection on a target language structure can arise out of a task focused on meaning. The class discusses a text of

${ }^{3}$ See Ellis (1995), who achieves results largely consistent with those reported here. 
Mark Twain about the difficulties of the German language. The students are asked to try to understand the text and to look for unknown words crucial to such an understanding. The sentence discussed in Transcript 1 below is: "Die Deutschen haben noch eine Art von Parenthese, die sie bilden, indem sie ein Verb in zwei Teile spalten und die eine Hälfte an den Anfang eines aufregenden Absatzes stellen und die andere Hälfte an das Ende" (The Germans have a type of parenthesis they form by splitting a verb into two parts and putting one half at the beginning and the other at the end of an exciting paragraph). The sentence catches the attention of one of the learners, as it itself represents a departure from the German word order rule, in accordance with which the verb (here: "stellen" / to put) should be located at the end of the subordinate clause (“... die andere Hälfte an das Ende stellen”). In other words, the German sentence contradicts its content via its form:

\section{Transcript 1:}

1 S1: ich habe da eine Frage im ersten Satz hier sagt "und die" blablabla "stellen"

I've got a question in the first sentence it says "und die" blablabla "stellen" und dann "und die" und es gibt nicht ein Verb am Ende and then "und die" and there is no verb at the end

$2 \mathrm{~T}$ : schön gesehen ja well noticed yes

3 S1: und warum ist "stellen" nicht am Ende?

and why is "stellen" not at the end?

$4 \mathrm{~T}$ : ja sagen Sie nochmal wie wäre die normale Wortstellung? okay tell us again what would be the normal word order?

5 S1: es wäre "die andere Hälfte an das Ende stellen" it would be "die andere Hälfte an das Ende stellen"

6 T: schön daß Sie das gesehen haben äh tja und warum ist es hier nicht so? great that you noticed that uhm yeah and why isn't it like that in this case?

7 S2 stilistisch stylistic

(Eckerth 1998, 60)

The student goes beyond the instruction to deal with the text on a semantic level, and focuses on a syntactic aspect of the foreign language sample. His question concerns the sentence final position of the verb in the subordinate clause, 
a rule that is (for stylistic reasons, as another student correctly states later on) violated in the discussed text. He notices this deviation from what he perceives as a target language rule and, following the teacher's encouragement to do so, formulates the non-deviating standard form. Such questions occur in numerous learner-initiated exchanges, as described in detail in Eckerth (1998). As they are considered to bear a substantial learning potential both for the initiating student as well as for the remaining class, some of their characteristics will be outlined.

Firstly, we may note that the initial learner question is not simply based on a gap in the student's interlanguage, but is based on previous L2 knowledge that is activated in the perception and processing of the input. Secondly, the noticed mismatch between previous L2 knowldege and the structure noticed in the input necessitates the allocation of considerable attentional resources, a depth of cognitive processing which can be assumed to be highly conducive to L2 acquisition ${ }^{4}$. Thirdly, going beyond the isolated sequence shown in Transcript 1, language-related learner questions typically lead to follow-up questions from other learners, and can in this way stimulate intensive discussion and negotiation of L2 learning problems. This so-called "snowball hypothesis" (Eckerth, 1999b) states that language-related learner questions can stimulate attention-raising on the part of co-learners, resulting in complex interactional patterns, and learning processes.

Whereas these results aim to contribute to a theory of instructed foreign language learning, and although transcripts like the one discussed above might be used in teacher training, their immediate benefit to language teaching and pedagogy is not evident. Nonetheless, investigations of this type can, I suggest, be highly relevant to foreign language pedagogy, namely in the sense of thesis three.

\subsection{Text reconstruction tasks}

Thesis 3 claims that the relevance of second language acquisition research for foreign language teaching shows in the degree to which the research accounts for the specific conditions of foreign language instruction. This is, for example, a central concern of classroom-based L2 research, in particular research into the interrelation between instruction, interaction, and acquisition (e.g. Hall \& Verplaetse, 2000; Eckerth, 2003b; Ohta, 2003). Such approaches seek to take into

\footnotetext{
${ }^{4}$ A brief look at the motivation of the student in transcript 1 may be instructive. This motivational back-ground is topicalised in the retrospective interview, where the student describes his personal learning style, which may be summa-rised as "analytic". His statement "I always want to know what is possible and what is not possible ... perhaps I am like a computer which must have an order in its knowledge" (Eckerth 1998, 140), reveals this student's preception of his own learning procedures, in particular his desire to bring some order into the 'untidy' world of foreign language learning.
} 
account factors characteristic of the learning environment under investigation, as interactional patterns are for example influenced by social context, didactic norms, and institutional conventions. They contrast with approaches that consider the language classroom as a place where language acquisition can be studied in vitro, due to its accessability and the high degree of control that can be imposed. This approach runs the risk of reducing the complexity of the teaching-learningrelationship, and of conceptualising 'instruction' as an unidimensional, monolithic construct (Felix \& Waigel, 1991, is a relevant example) ${ }^{5}$.

The claim that second language acquisition research should take into consideration the particular conditions of the L2 classroom does not limit the role of classroom-based research to pure observation. Classroom-based research may be interventional in character, and still match the requirement of thesis 3 above. This will be exemplified by an investigation of task-based learner-learner interaction (Eckerth 1999c). This study is built on the results of research into language-related learner questions discussed above. A main concern was how far the development, negotiation, and testing of L2-hypotheses could systematically be built into classroom procedures.

Transcript 2 shows a sequence from a text reconstruction task carried out in a Dutch secondary school with students in their third year of German as a Foreign Language. After listening twice to a short text, and taking notes, the students had to jointly reconstruct the text as closely to the original as possible, i.e. both with respect to the content and to form. ${ }^{6}$ The structural focus of the task is prepositional expressions of location and direction ("she is in the disco" vs. "she goes into the disco"). In German, the same preposition may often be used, with either the dative case ("sie ist in der Disko"), signalling location, or the accusative case ("sie geht in die Disko"), signalling directionality. In Transcript 2, the accusative case is appropriate.

\section{Transcript 2:}

Sentence to be reconstructed:

“... wenn ich mit meinen Freunden und Freundinnen in die Disko [ACC] oder ins Kino [ACC] gehen kann."

"... if I can go to the disco or to the movies with my friends."

5 Having put forward this claim, I would like to emphasize that such a postulate does by no means rule out other, more experiementally-oriented approaches to second language acquisition research (see e.g. Hulstijn 1997 on the possibilities and limitations of SLA research in the laboratory).

6 The text reconstruction task used here is a development of what Swain (Swain 1995; Swain \& Lapkin 2001) calls a 'collaborative language production task'. 
1 S1: [schreibt] "dann geht sie (...) mit Freunden und (..) Freundinnen"

$$
\text { (..) ins Kino? }
$$

2 S2: (..) oder

3 S1: [schreibt] "ins (.) Kino"

4 S2: in (..) äh Disko

5 S1: oder (.) in die Disko?

6 S2: (...) in die oder in der? sie geht da hin (.) wohin (.) das ist ein Weg (.) Akkusativ (...) in die Disko

7 S1: okay (..) in die Disko [writes] "then she goes (...) with boy friends and (..) girl friends"

(..) to the movies? [ACC]

(..) or

[writes] "to the (.) movies" [ACC]

o (..) uh disco

or (.) to the disco? [ACC]

(...) to the $[\mathrm{ACC}]$ or to the $[\mathrm{DAT}]$ ?

she goes there (.) where to (.)

that's a direction (.)

accusative case (...) to the disco

okay (..) to the disco [ACC]

Student 1 writes down the part of the sentence which has been discussed so far, checking the appropriateness of 'ins Kino' by means of a rising intonation. Student 2 does not react, however, as she is already busy planning the next text segment (line 2), so student 1 writes down the critical prepositional phrase (line 3 ). In the following exchange student 2 hesitates (line 4), unsure as to which grammatical case to use. S1 puts forward a correct proposal, without giving any reasons for it (line 5). This proposal sets off a process of reflection by student 2. On the basis of a learned didactic rule (where=dative case; where to=accusative case), retrieved step by step from memory (line 6), she is finally in a position to formulate the correct expression.

I would argue that the exchange given in transcript 2 has rich potential for second language learning. In a study investigating peer group text production tasks, Dam et al. (1990: 327) state: “(...) we think it is one of the advantages of group writing that learners have to make explicit their ideas and, if necessary, support them by further arguments. This means that, on the one hand, they are forced to engage actively in the evaluative process, and on the other hand, they get immediate feedback on their own proposals". This is exactly what happens in transcript 2.

More generally speaking, by making the target language itself the content of thetask, so called consciousness-raising tasks such as the one featured above bring about a dual focus on meaning and form (Eckerth 1999c), as they require learners to talk about the target language in the target language. Furthermore, as could be seen in transcript 2, consciousness-raising tasks are a suitable way to encourage 
L2-hypothesis building and testing by learners. In free writing activities, or unfocused communicative tasks, all sorts of reduction and avoidance strategies can be employed. However, consciousness-raising tasks of the kind under discussion here focus on a particular structural L2-feature, and this focus cannot be strategically circumvented.

Clearly, then, L2 tasks of this kind are to be considered not only as a research instrument, a way to collect data, but also as an instrument for instruction, thus bridging the gap between second language acquisition research and foreign language teaching.

\section{The notion of task as a conceptual link between L2 teaching and L2 research}

The task is modelled as a conceptual link between L2 teaching and L2 research in figure 1. The model focuses on task-based interaction, and addresses two basic questions: What kind of language use is brought about by a certain task, and to what degree has this language use the potential to foster acquisition? The first question addresses the kind of linguistic and communicative forms that are used during task completion, whereas the second question is concerned with the acquisitional functions of these forms. In the following, I will briefly comment on these notions.

In task-based teaching, tasks are primarily understood as arranged didactic settings in which pairs or groups of learners have to solve a communicative problem by using the target language orally and/or in writing. Thus, for example, the imperative might be used to communicate a recipe to a friend, prepositional expressions of location to identify differences in two similar pictures, or directives to orientate a stranger in town. The overall goal of such tasks is to engage students in types of transactional and/or interactional communication. Thus, what I wish to term linguistic forms (see figure 1) are those target language forms and structures which are used productively or receptively by the students during task completion. When using these forms in order to achieve a communicative goal, students almost inevitably encounter communicative problems due to their limited L2 competence. In order to overcome these problems, the learners can employ different means of interactional management, for example confirmation checks or clarification requests for the negotiation of meaning, paraphrasing, substitution, or embedding to modify output, as well as all types of productive and receptive communication strategies. Such devices I wish to term communicative forms (see figure 1).

What about the acquisitional functions of these forms? Whereas task-based teaching uses tasks in order to elicit, use, and practice linguistic and communicative target language forms, task-based research asks in what way and to 
what degree the mental processes that are involved in the use of such forms are conducive to L2 learning. In figure 1, these mental processes are divided into cognitive processes and linguistic processes. Cognitive processes are activated into order to plan task execution, e.g. processes such as selecting, classifying, and deducing information from the task specification. The amount of cognitive processing necessary for task execution therefore directly reflects task complexity. Linguistic processes, however, involve the perception, noticing, selection, processing and production of target language elements from the task description and from memory. The relationship between these two variables, as well as their impact on L2 learning, is a point of some controversy. Robinsohn's Cognition Hypothesis of task-based L2 development claims for example that cognitively more demanding tasks will lead to the use of lexically and syntactically more complex language (Robinson 2001a, b), while a different viewpoint is held by Skehan (1998) and Skehan \& Foster $(1999,2001)$, who hypothesise that the more attention required for a task because of its cognitive complexity, the less complex will be the linguistic output.

Investigating this inter-relationship between task features, language use, and language acquisition requires the systematic variation of task characteristics in order to assess their effect on learning activities and learning gains. As was claimed by thesis 1 and shown in the investigation of uptake-recall charts, such research may require elaborate and technical methodological procedures, that nevertheless yield instruments which can readily be implemented in L2 teaching. Furthermore, as claimed in thesis 3 and shown in the study of text reconstruction tasks, such research activities should also attempt to take into consideration the inherent conditions and characteristics of the foreign language classroom. In fact thesis 2 , which was substantiated by an investigation of language-related learner questions, considered this to be a basic criterion for the pedagogical relevance of L2 research. Yet it has to be recognized that the bulk of task-based research is carried out under experimental conditions. In cases where task-based learning has been investigated in regular classrooms, the findings often differ considerably from results achieved under experimental conditions, both in terms of quantity as well as in quality of performance features. With regard to meaning negotiation, for example, classroombased studies of task-based learner-learner-interaction (Foster 1998; Eckerth, 2003, under review) were able to show that students do not apply a "check and clarify" strategy, as in experimental studies, but rather a "pretend and hope" strategy (Foster 1998: 19). Subjects see extensive meaning negotiation as time-consuming, 
as a potential disturbance of the communication, and as face-threatening. ${ }^{7}$ Evaluations of these tasks, then, if conducted by teachers in their own classrooms, can serve as a means of testing the transferability of research findings, and establish a closer relationship between L2 research and L2 teaching. Figure 1 models this reciprocal process, whereby complementary areas of expertise join in the mutual endeavour to understand language learning and to increase the efficacy of language teaching:

Figure 1: Task as a conceptual link between $L 2$ teaching and L2 research

Task Design
Pedagogic Use

7 Furthermore, these studies showed that task-based performance varied enormously, as much due to inter-individual variation as to task characteristics. Though not considered in figure 1 , the influence of individual variation and affective variables such as motivation, attitude, and learning goals on task performance and language acqusition should be added to the agenda of task-based research (see Eckerth \& Riemer 2000 for further arguments on this subject). 


\section{Summary and final remarks}

In this paper, I have attempted to shed some light on the relationship between theory and practice in L2 research and teaching by discussing three empirical studies carried out in the field of classroom-based second language acquisition research. My point of departure was the observation that communication between those engaged in L2 research and those active in L2 teaching is complicated by the constraints operating for these two professional communities. Three proposals regarding the pedagogic relevance of second language acquisition research were put forward, and given substance through the discussion of empirical L2 research. These theses claimed (i) that even if the research process might be highly technical in nature and remote from everyday's teaching, the resulting research product can be of immediate applicability, (ii) that such an immediate applicability of research results is just one of several possible relevance criteria, and (iii) that the degree to which pedagogical relevance is obtained corresponds with the degree to which empirical research takes into consideration the inherent conditions and characteristics of the foreign language classroom. Finally, I have sought to show how L2 research and L2 teaching can mutually inform each other, both contributing to the goal of better understanding and promoting L2 development, and to the better understanding of each other. I suggest that research cannot provide definite answers as to how language teaching should be conducted. This is neither a feasible, nor a sensible goal. Rather research should attempt to challenge popular assumptions about teaching, and provide insights about the teaching-learningrelationship in the L2 classroom. Such findings, then, can be integrated into an ongoing process of teaching exploration, evaluation, and development.

\section{References}

Allwright, R. L. (1984). Why don't learners learn what teachers teach? - The interaction hypothesis. In: Singleton, D. M. \& Little, D. G. (eds.), Language learning in formal and informal contexts. Dublin: IRAAL, 3-18.

Corder, S. P. (1981). The role of interpretation in the study of learners' errors. In: Corder, S. P., Error analysis and interlanguage. Oxford: Oxford University Press, 3544.

Coughlan, P. \& Duff, P. (1994). Same task, different activities: Analysis of SLA task from an activity theory perspective. In: Lantolf, J. \& Appel, G. (eds.), Vygotskian approaches to second language research. New Jersey: Ablex, 173-193. 
Dam, L., Legenhausen, L., \& Wolff, D. (1990). Text production in the foreign language classroom and the word processor. In: System 18, 325-334.

Eckerth, J. (1998). Kognitive Aspekte sprachbezogener Lernerfragen. Interaktion und Kognition im Deutsch-als-Fremdsprache-Unterricht [Cognitive aspects of language-related learner questions. Interaction and cognition in the Germanas-a-Second-Language classroom]. Baltmannsweiler: Schneider Verlag Hohengehren.

Eckerth, J. (1999a). Assessing learning opportunities in the L2 classroom: Investigating the validity and reliability of uptake-recall charts. Utrecht University, mimeo.

Eckerth J. (1999b). Interaction and participation in the foreign language classroom: The snowball hypothesis. In: Proceedings from the 6th International NELLEConference, Bielefeld, 25-30.

Eckerth, J. (1999c). Negotiation of target language discourse in foreign language learning: focus on form and meaning. In: Toegepaste Taalwetenschap in Artikelen 61, 75-83.

Eckerth, J. (2003a). Fremdsprachenerwerb in aufgabenbasierten Interaktionen [Second language acquisition through task-based interaction]. Tübingen: Narr.

Eckerth, J. (ed.) (2003b). Empirische Arbeiten aus der Fremdsprachenerwerbsforschung. Beiträge des Hamburger Promovierendenkolloquiums Sprachlehrforschung [Second language acquisition research: Contributions of the Hamburg Ph.D.Research Forum]. Bochum: AKS-Verlag.

Eckerth, J. (under review). Second language acquisition through task-based interaction: Investigating learning processes and learning gains.

Eckerth, J. (in preparation). Autonomous learning in task-based learner-learner-interaction. Will be submitted to: Language Teaching Research.

Eckerth, J. \& Riemer, C. (2000). Awareness und Motivation: Noticing als Bindeglied zwischen kognitiven und affektiven Faktoren des Fremdsprachenlernens [Awareness and motivation: noticing as link between cognitive and affective factors in foreign language learning]. In: Riemer, C. (ed.), Kognitive Aspekte des Lehrens und Lernens von Fremdsprachen / Cognitive aspects of foreign language learning and teaching. Studies in honour of Willis J. Edmondson. Tübingen: Narr, 228-246.

Ellis, R. (1995). Uptake as language awareness. In: Language Awareness 4, 147-160.

Ellis, R. (1997). SLA research and language teaching. Oxford: Oxford University Press.

Felix, S. \& Weigl, W. (1991). Universal grammar in the classroom: The effects of formal instruction on second language acquisition. In: Second Language Research $72,162-181$.

Foster, P. (1998). A classroom perspective on the negotiation of meaning. In: Applied Linguistics 19, 1-23.

Gee, J. (21996). Social linguistics and literacies. Ideology in discourses. London: Taylor \& Francis. 
Hall, J. K. \& Verplaetse, L. S. (eds.) (2000). Second and foreign language learning through classroom interaction. Mahwah, NJ: Lawrence Erlbaum.

Hulstijn, J. (1997). Second language acquisition research in the laboratory: possibilities and limitations. In: Studies in Second Language Acquisition 19, 131-143.

Kramsch, C. (1995). The applied linguist and the foreign language teacher: Can they talk to each other? In: Australian Review of Applied Linguistics 18, 1-16.

Long, M. (1983). Native-speaker/non-native speaker conversation and the negotiation of comprehensible input. In: Applied Linguistics 4, 126-141.

Long, M. (1996). The role of the linguistic environment in second language acquisition. In: Ritchie, W. C. \& Bhatia, T. K. (eds.), Handbook of second language acquisition. San Diego: Academic Press, 413-468.

Pica, T. (1997). Second language teaching and research relationships: A North American view. In: Language Teaching Research 1, 48-72.

Robinson, P. (2001a). Task complexity, difficulty and lexical variety. In: Applied Linguistics 22, 27-57.

Robinson, P. (2001b). Task complexity, cognitive resources, and syllabus design: A triadic framework for examining task influences on SLA. In: Robinson, P. (ed.), Cognition and second language instruction. Cambridge: Cambridge University Press, 287-318.

Skehan, P. (1998). A cognitive approach to language learning. Oxford: Oxford University Press.

Skehan, P. \& Foster, P. (1999). The influence of task structure and processing conditions on narrative retellings. In: Language Learning 49, 93-120.

Skehan, P. \& Foster, P. (2001). Cognition and tasks. In: Robinson, P. (ed.), Cognition and second language instruction. Cambridge: Cambridge University Press, 183205 ..

Slimani, A. (1989). The role of topicalization in classroom language learning. In: System 17, 223-234.

Slimani, A. (1992). Evaluation of classroom interaction. In: Alderson, J.C. \& Beretta, A. (eds.), Evaluating second language education. Cambridge: Cambridge University Press, 197-220.

Swain, M. (1985). Communicative competence: some roles of comprehensible input and comprehensible output in its development. In: Gass, S. M. \& Madden, C. (eds.), Input in second language acquisition. Rowley, MA: Newbury House, 235-253.

Swain, M. (1995): Three functions of output in second language learning. In: Cook, G. \& Seidlhofer, B. (eds.), Principle \& practice in Applied Linguistics. Studies in honour of H. G. Widdowson. Oxford: Oxford University Press, 125-144.

Swain, M. \& Lapkin, S. (2001). Focus on form through collaborative dialogue: Exploring task effects. In: Bygate, M.; Skehan, P. \& Swain, M. (eds.), Researching pedagogic tasks. Second language learning, teaching and testing. London: Longman, 99-118. 